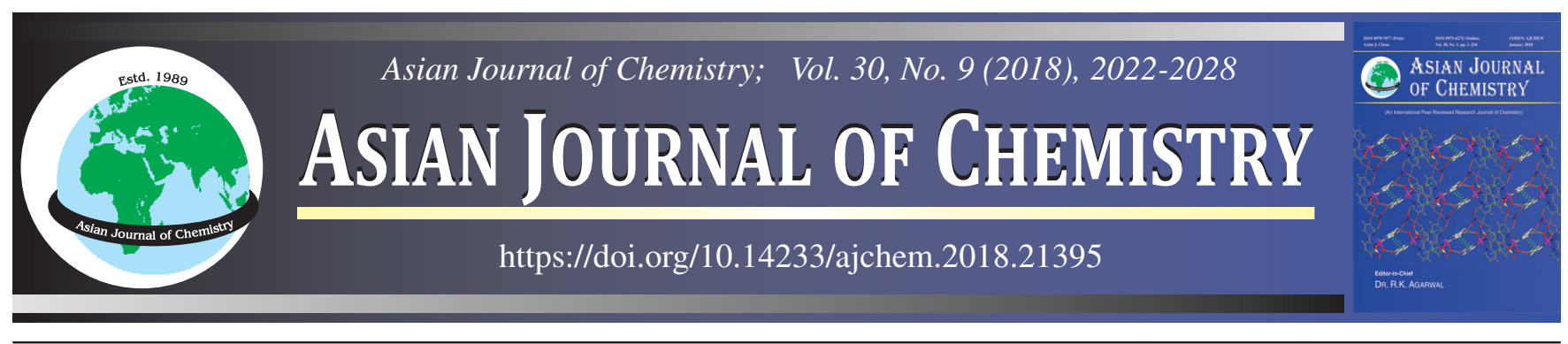

\title{
Simultaneous Determination of Sodium, Potassium and Magnesium Counter Ions in Three Drugs: Pantoprazole Sodium, Losartan Potassium and Omeprazole Magnesium by Ion Chromatography
}

\author{
Nagaraju Rajana ${ }^{1,2, *}$, B. SRikanth ${ }^{1}$, D.V. Ramana ${ }^{1}$, Kaviraj M. Yarbagi $^{1}$, \\ P. Madhavan ${ }^{1}$, J. Moses Babu ${ }^{3}$, K. Basavaiah ${ }^{2}$ and Dharamasoth Rama Devi ${ }^{4}$
}

${ }^{1}$ Technology Development Center, Custom Pharmaceutical Services, Dr. Reddy's Laboratories Ltd., Miyapur, Hyderabad-500 049, India ${ }^{2}$ Department of Inorganic \& Analytical Chemistry, Andhra University, Visakhapatnam-530 003, India

${ }^{3}$ Integrated Product Development Organization, Dr. Reddy's Laboratories, Innovation Plaza, Bachupally, Hyderabad-500 072, India

${ }^{4}$ Andhra University College of Pharmaceutical Sciences (Andhra University), Visakhapatnam-530 003, India

*Corresponding author: E-mail: nagarajurajana@drreddys.com; nagarajrajana@gmail.com

Received: 20 April 2018;

Accepted: 6 June 2018;

Published online: 31 July 2018;

AJC-19014

The present analytical method was developed for single determination of three counter ions in pantoprazole sodium, losartan potassium and omeprazole magnesium drug substances by ion chromatography. The ion chromatography method was unique and suitable for three drugs such as pantoprazole sodium, losartan potassium and omeprazole magnesium with specification limits $5.7,8.5$ and $3.3 \%$ of percentages of sodium, potassium and magnesium counter ions, respectively. The method was developed with Metrosep $\mathrm{C}_{4}(150 \times 4.0$ $\mathrm{mm}, 5 \mu$ ) column and combination of $4.0 \mathrm{mM}$ nitric acid, $0.1 \%$ dipicolinic acid and $10 \%$ acetonitrile with flow of $1 \mathrm{~mL}$. The injection volume used for this analysis was $20 \mu \mathrm{L}$ with conductivity detector. The validation was performed to single ion chromatography method for three counter ions such as sodium in pantoprazole sodium, potassium in losartan potassium and magnesium in omeprazole magnesium. The $\%$ RSD for the method precision and intermediate of sodium in the pantoprazole sodium was $1.6 \%$ and $1.6 \%$, respectively. The correlation coefficient for the linearity parameter of the sodium in the pantoprazole sodium was 1.000 . The accuracy of sodium in pantoprazole sodium was observed as 97, 101 and $103 \%$ recovery at 50, 100 and $150 \%$, respectively. The \% RSD for the method precision and intermediate of potassium in the losartan potassium was $2.0 \%$ and $1.5 \%$, respectively. The correlation coefficient for the linearity of the potassium in the losartan potassium was 0.999 . The accuracy of potassium in losartan potassium was observed as 97.2 , 100.0 and $101.8 \%$ recovery at 50, 100 and $150 \%$, respectively. The $\%$ RSD for the method precision and intermediate precision of magnesium in the omeprazole magnesium was 1.7 and $2.0 \%$, respectively. The correlation coefficient for the linearity of the magnesium in the omeprazole magnesium was 1.000. The accuracy of magnesium in omeprazole magnesium was observed as $113.1,98.5$ and $98.5 \%$ recovery at 50,100 and $150 \%$, respectively. The robustness study was performed for flow of mobile phase from the actual flow and acetonitrile concentration. All the robustness values were less than the $10 \%$ of initial counter ion content. The developed and validated method can be used for the simultaneous determination of sodium, potassium and magnesium counter ions in pantoprazole sodium, losartan potassium and omeprazole magnesium, respectively.

| Keywords: Pantoprazole sodium, Losartan potassium, Omeprazole magnesium, Counter ions, Validation, Ion chromatography.

ᄂ _ - _ - - _ - - - - - - - - - - - - - - - - - - - - - - - - - -

\section{INTRODUCTION}

The cationic counter ions are useful for the stability of pharmaceutical drug substances and drug product. As per the ICH Q1, the stability of the drug substance and drug product will be varying by not only the chemical entity of drug substances and also the counter ions or the excipient [1]. The cations such as sodium, potassium, magnesium and calcium, generally can used for the stability of the active pharmaceutical ingredients and also to show different biological activities, [2]. The different ratios of inorganic counter ions $(\mathrm{Na}, \mathrm{Mg}, \mathrm{Li}, \mathrm{K}$ and $\mathrm{Ca})$ of drug substance will give different polymorphs [3]. The ratios of counter ion in the drug need to know for the potency of drug substance and activity of drug substances [4]. The

This is an open access journal, and articles are distributed under the terms of the Creative Commons Attribution-NonCommercial 4.0 International (CC BY-NC 4.0) License, which allows others to copy and redistribute the material in any medium or format, remix, transform, and build upon the material, as long as appropriate credit is given and the new creations are licensed under the identical terms. 
present study describes determination of sodium in pantoprazole sodium, potassium in the losartan potassium and magnesium in the omeprazole magnesium. The pantoprazole sodium is name of sodium; 5-(difluoromethoxy)-2-[(3,4-dimethoxypyridin-2-yl)methylsulfinyl]benzimidazol-1-ide (Fig. 1). It inhibits the gastric acid secretion, it is a proton pump inhibitor helps to cure the ulcers, gastroesophageal reflux disorder (GERD), erosive esophagitis and Zollinger-Ellison syndrome. It is functioning by blocking acid production in the stomach. The percentage of sodium in pantoprazole sodium is 5.7. The sodium amount needs to quantify in the pantoprazole sodium drug to calculate the potency of drug substance. Losartan potassium is the potassium; [2-butyl-5-chloro-3-[[4-[2-(1,2,3triaza-4-azanidacyclopenta-2,5-dien-5-yl)phenyl]-phenyl]methyl]imidazol-4-yl]methanol (Fig. 1). The losartan potassium is angiotensin-II-receptor antagonist used for the treatment of hypertension and heart failure. It decreases sodium excretion, increases potassium excretion and acts as a vasoconstrictor in vascular muscle $[5,6]$. The percentage of potassium in losartan potassium is 8.5. The potassium amount needs to quantify in the omeprazole magnesium drug to calculate the potency of drug substance. Omeprazole magnesium is magnesium; 6-methoxy-2-[(4-methoxy-3,5-dimethylpyridin2-yl)methylsulfinyl]-1H-benzimidazole (Fig. 1), it uses for treatment of dyspepsia, peptic ulcer disease, Laryngopharyngeal reflux, Zollinger-Ellison syndrome and gastro oesophageal reflux diseases [7]. The percentage of magnesium in omeprazole magnesium is 3.3. The magnesium amount needs to quantify in the omeprazole magnesium drug to calculate the potency of drug substance. Several ion chromatographic methods were available to determine the cations in environmental samples and food samples [8-17] but no method was reported for counters ion in the drug substances of pantoprazole sodium losartan
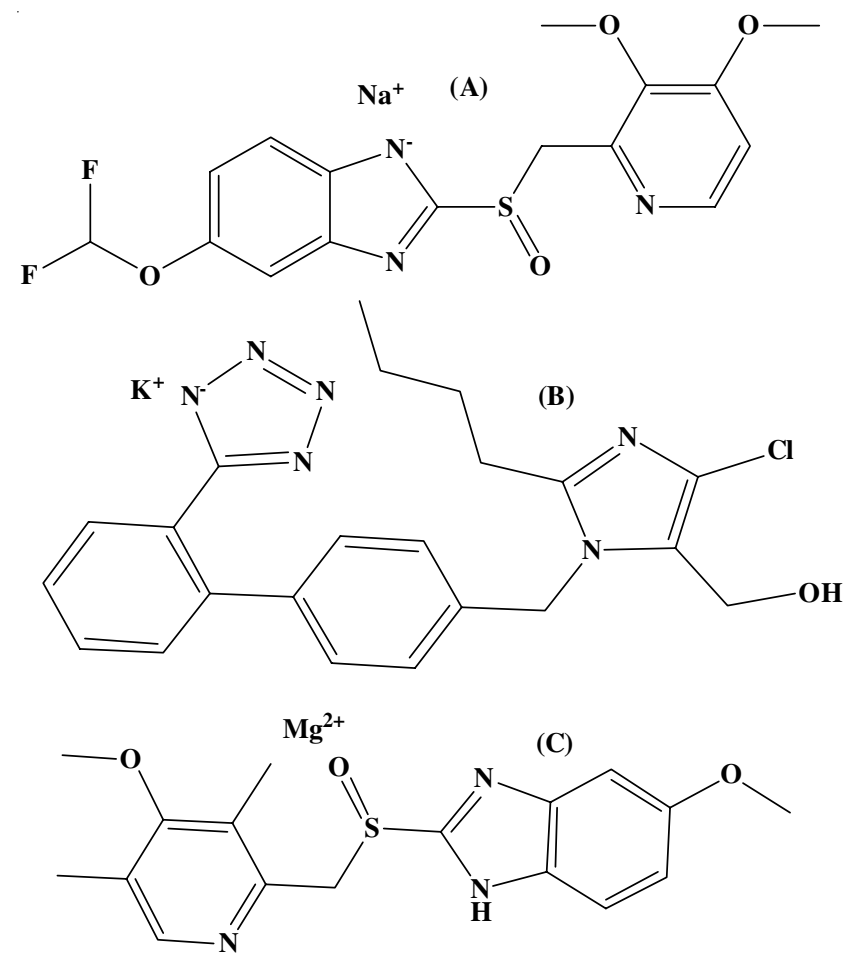

Fig. 1. Selected API's (A) Pantoprazole sodium (B) Losartan potassium (C) Omeprazole magnesium potassium and omeprazole magnesium by ion chromatography. Many high performance chromatography and mass spectrometry methods were available for determination of drug substance as pantoprazole [18-27], losartan [27-35] and omeprazole [36-47].

The present work also describes the counter ions contribution in pantoprazole sodium, losartan potassium and omeprazole magnesium drug substances by ion chromatography technique. The single ion chromatography method was developed for the determination of sodium, potassium and magnesium in respective drug substances of pantoprazole sodium, losartan potassium and omeprazole magnesium. The ion chromatography method was validated against the ICHQ2 (R1) and USP analytical method validation procedures [48-50]. The other conventional and instrumental methods were used for determination sodium, potassium and magnesium in water and other type samples but they are more time taking procedure with high sample quantity, lengthy and more unsafe procedures [51-56]. The authors developed and validated ion chromatography technique requires less than $1 \mu \mathrm{g}$ of sample for analysis and universally accepted chromatograms.

\section{EXPERIMENTAL}

Analytical grade acetonitrile was purchased from the Avanar Performance Material Mumbai, India. Analytical grade sodium chloride, potassium iodide and magnesium iodide was purchased from the Sigma Aldrich Merck Mumbai, India. The analytical grade nitric acid purchased from Qualigens fine chemicals, Mumbai, India. 1,4-Dipicolinic acid was purchased from S.D. Fine Chemicals, Mumbai, India. High pure water was collected from a Millipore Milli-Q Water purification system (Millipore, Milford, MA, USA). The drug substances of pantoprazole sodium, losartan potassium and omeprazole magnesium for research obtained from Dr. Reddy's Laboratories Ltd., Hyderabad, India.

Equipment: The complete study was performed with the Metrohm ion chromatographic system with Magic Net 3.2 software. The instrument was purchased from the Metrohm Ltd.CH-9101 Herisau, Switzerland. It is equipped with 818 IC Pump, 833 liquid handling unit, sampling injector loop is $20 \mu \mathrm{L}$ loop, $820 \mathrm{IC}$ separation centre and conductivity detector. The dilutions were performed by using gastight syringes. The polypropylene vials were used for injecting the samples, these are provided by Metrohm.

Method development and optimization of ion chromatographic method: The chromatographic conditions were optimized by using different mobile phase ratios such as acid concentrations, different buffer concentrations, different solvent concentrations (acetonitrile and acetone), different ratio of diluent (ratios of acetonitrile and water), different injection loop volumes (10, 20, 50 and $100 \mu \mathrm{L})$, different columns and different flow rates $(0.7 \mathrm{~mL} 1.0 \mathrm{~mL})$.

Standards and sample preparations: Standards preparations counter ion at specification level.

Preparation of standard stock solution of sodium: Weigh about $25 \mathrm{mg}$ of sodium chloride in $100 \mathrm{~mL}$ volumetric flask containing the diluent and made up to the mark with diluent and sonicate to dissolve the standard. 
Preparation of standard stock solution of potassium: Weigh about $40 \mathrm{mg}$ of Potassium iodide in $100 \mathrm{~mL}$ volumetric flask containing the diluent and made up to the mark with diluent and sonicate to dissolve the standard.

Preparation of standard stock solution of magnesium: Weigh about $100 \mathrm{mg}$ of magnesium iodide in $100 \mathrm{~mL}$ volumetric flask contain the diluent and made up to the mark $\mathrm{w}$ it diluent and sonicate to dissolve the standard.

Preparation of premixed standard solution at counter ion specification level: Transfer the $10 \mathrm{~mL}$ of each sodium, potassium and magnesium stock solution into the $100 \mathrm{~mL}$ volumetric flask and make up to the mark with diluent, cyclomix to dissolve standard solution.

\section{Sample preparations}

Preparation of stock solution (pantoprazole sodium): Weigh about $25 \mathrm{mg}$ of pantoprazole sodium and transferred into the $25 \mathrm{~mL}$ volumetric flask and made up to the mark with diluent and sonicate to dissolve the sample.

Preparation of stock solution (losartan potassium): Weigh about $100 \mathrm{mg}$ of losartan potassium and transferred into the $50 \mathrm{~mL}$ volumetric flask and made upto the mark with diluent and sonicate to dissolve the sample.

Preparation of stock solution (omeprazole magnesium): Weigh about $25 \mathrm{mg}$ of omeprazole magnesium and transferred into the $25 \mathrm{~mL}$ volumetric flask and made up to the mark with diluent and sonicator to dissolve the sample.

Preparation of premixed sample solution at counter ion specification level: Transfer the $5 \mathrm{~mL}$ of each pantoprazole sodium, losartan potassium and $7.5 \mathrm{~mL}$ of omeprazole magnesium sample stock solution into the $25 \mathrm{~mL}$ volumetric flask and make up to the mark with diluent and cyclomix to sonicate the standard solution.

Method for determination of sodium, potassium and magnesium counter ions in drug substances: After optimized chromatographic conditions, the flow of mobile phase stabilized to run until neat base line. Injected the two diluent (water) injection followed by the five mixed standards of sodium, potassium and magnesium at counter ion specification level. Once the five injections were run, calculate the \% RSD for the area of respective counter ions.

$$
\operatorname{RSD}(\%)=\frac{\text { Standard deviation of five standards }}{\text { Average area of five standards }} \times 100
$$

Once five standards were run, calculate the $\%$ RSD. Those should be within the $10 \%$ the injected diluted samples (each pantoprazole sodium, losartan potassium and omeprazole magnesium sample). Record the response of the each ion from mixture of sample solution. The following formula has been used to determine the percentage of counter ion in mixed sample solution. This procedure has been applied for individual drug substance also.

$$
\mathrm{Na} / \mathrm{K} / \mathrm{Mg}(\%)=\frac{\mathrm{TSA} \times \mathrm{TSW} \times \mathrm{SD} \times \mathrm{CF}}{\mathrm{SA} \times \mathrm{SW} \times \mathrm{SD}} \times \text { Potency }
$$

where: TSA: Test sample area, TSW: Test sample weight, SW: Sample weight, SD: Sample dilution, SA: Standard area, C.F: Correction Factor of standard. Potency: standard potency.
Validation of ion chromatographic method: The developed method was validated as per the ICH Q2 (R1) guideline and USP general chapter-1225: Validation of compendial procedure for the validations parameters such as precision, accuracy, linearity, range, robustness, specificity, solution stability and mobile phase stability.

Precision: Precision for developed method was performing as method precision and intermediate precision. Method precision was performing with same sample with six different specification level preparation solution. The content of each solution evaluated and calculated the coefficient variation. Similarly different day with different column, different mobile phase used for the intermediate precision and evaluated the coefficient variation. Three concentrations were studied for $\%$ RSD i.e. 50, 100 and $150 \%$.

Accuracy: Accuracy is difference between the observed the per cent of counter ions and with calculated value of ions in drug substance. This was studied by choosing the three concentrations like 50, 100 and $150 \%$, calculated the content of each solution. The per cent recovery was calculated with method precision solution. The following formula was used to determine the \% recovery of counter ion in the drug substance.

$$
\text { Recovery }(\%)=\frac{\mathrm{B}-\mathrm{A}}{\mathrm{C}} \times 100
$$

where: B: amount of counter ion in spiked sample; A: amount of counter ion in as such sample; $\mathrm{C}$ : amount of counter ion in standard.

Linearity and range: The seven series of standards were used to determine the linearity range. From this range, the counter ion can be determined. The calibration curve was determined by drawing the graph between the concentration on ' $\mathrm{X}$ ' axis and area on the ' $\mathrm{Y}$ ' axis. The correlation coefficient, intercept, slope and STEYX were calculated.

Robustness: For performing the robustness parameter, the actual method parameters varied such as flow varied $\pm 10 \%$ from the actual flow, buffer concentration $\pm 10 \%$ varied from actual, the solvent concentration $\pm 10 \%$ varied from actual, flow $\pm 10 \%$ from actual, the solvent concentration $\pm 10 \%$ varied from actual and acid concentration $\pm 10 \%$ varied from actual, the acid $\pm 10 \%$ varied from actual. The retention times, the coefficient variation was calculated.

Specificity: Specificity was performed by injecting the other counter ions. The other counter ions were specify with the determined counter ions, the retention times, the areas of the three ions were evaluated in presence of other counter ions.

Solution stability and mobile phase stability: The sample solution stability and mobile phase stability were performed for the 3 day $(72 \mathrm{~h})$. The variations of counter ions content from the initial contents were evaluated. The stored test sample was injected by $0,12,24,48 \mathrm{~h}$ and $72 \mathrm{~h}$. Interval and calculated the $\%$ difference between initial and each interval, similarly fresh was used in store the mobile phase. The $\%$ difference contents were evaluated by storing the mobile phase and injecting sample by $0,12,24,48$ and $72 \mathrm{~h}$ intervals. The following formula was used to calculate the solution stability.

$$
\frac{\% \text { Variation of counter ion in solution }}{\text { Mobile phase stability }}=\frac{\mathrm{FC}}{\mathrm{IC}} \times 100
$$


where FC: amount of counter ion at different intervals sample (e.g. 12, 24, 48 and $72 \mathrm{~h}$ ); IC: amount of counter ion in initial sample.

\section{RESULTS AND DISCUSSION}

Method development and optimization single counter ion chromatographic method: The initial method development has been started with the Metrosep $\mathrm{C}_{4}(150 \times 4.0 \mathrm{~mm}, 5$ $\mu$ column and $3.0 \mathrm{mM} \mathrm{HNO}_{3}$ in Milli-Q water:acetone (95:5 $\%$ ) mobile phase. The flow used for separation was $0.9 \mathrm{~mL} /$ $\mathrm{min}$ and run time was $20 \mathrm{~min}$. The injection loop volume was $20 \mu \mathrm{L}$ and the diluent concentration was 50:50\% of the acetonitrile and water. The magnesium eluted was about $11.12 \mathrm{~min}$ and the base line was with full of noise in conductivity detector with these method conditions (Fig. 2).
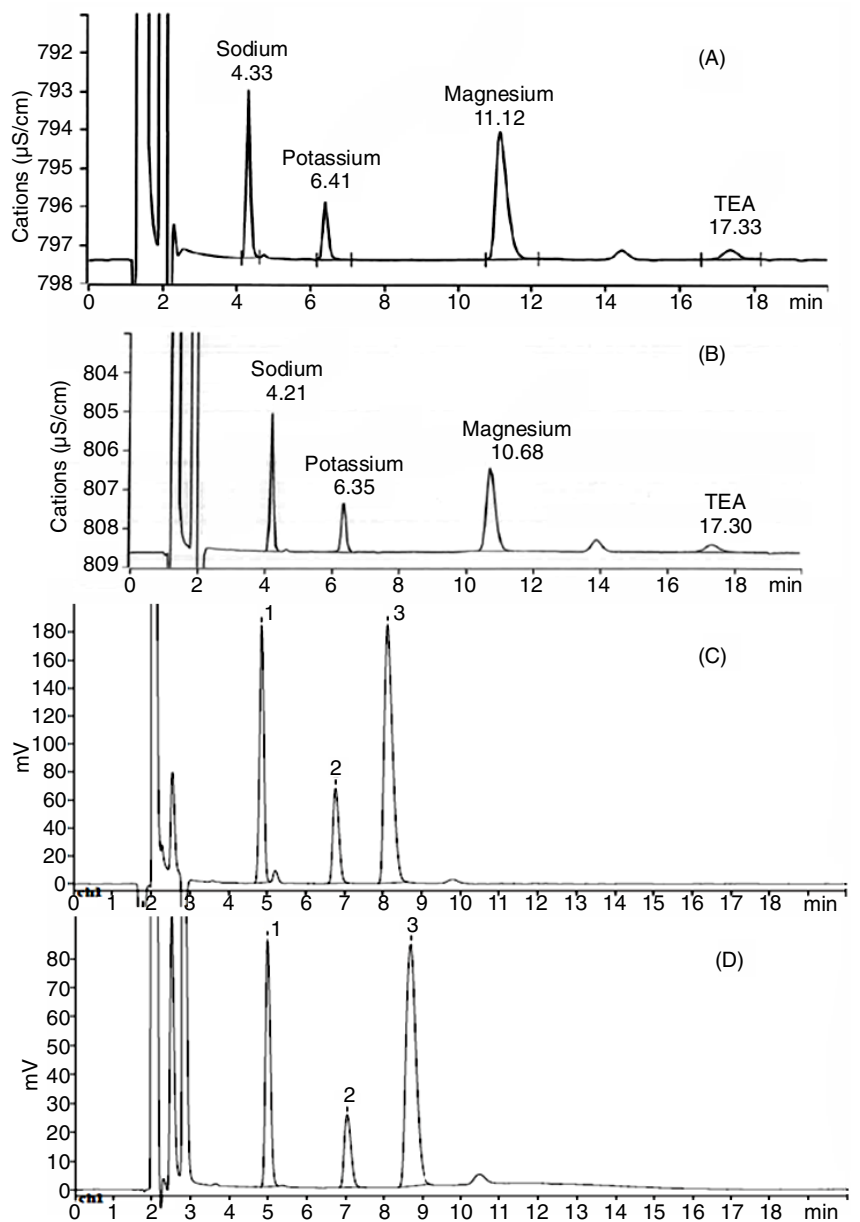

Fig. 2. Typical method development chromatograms (A) Method development trial-1 (B) Method development trial-2 (C) Method development trial-3 (D) Method developmenttrial-4

In the second trial, the acetone was replaced with the acetonitrile by keeping remaining all conditions similar; the magnesium peak was still not good than previous trial. This was due to acetonitrile in presence of $3 \mathrm{mM}$ nitric acid (Fig. 2). In the third trial, the nitric acid mobile phase replaced with $4.0 \mathrm{mM}$ tartaric acid $+0.75 \mathrm{mM}$ dipicolinic acid in water and $10 \%$ acetonitrile; the flow used in this trial was $1.0 \mathrm{~mL} / \mathrm{min}$. The column used in this trial was Metrosep $\mathrm{C}_{4} 250 \times 4.0 \times$ $250 \mathrm{~mm} \times 5.0 \mu \mathrm{m}$. The run time was $20 \mathrm{~min}$ and injection loop volume was $20 \mu \mathrm{L}$. The concentration of counter ions was 25 , $25,100 \mu \mathrm{g} / \mathrm{mL}$ of sodium, potassium and magnesium, respectively. All these peaks were eluted early when compared to the second method development trail because selection of mixture of two weak buffers (Fig. 2). Hence in the fourth trial, the mixer of strong and weak buffer along with organic solvent used, The column used in this trail was $\mathrm{C}_{4} 250 \times 4.0 \times 250 \mathrm{~mm} \times 5.0 \mu \mathrm{m}$ and the mobile phase was $3 \mathrm{mM}$ nitric acid, $0.1 \mathrm{mM}$ dipicolinic acid in water and $10 \%$ acetonitrile. The injection loop volume was $20 \mu \mathrm{L}$. The flow used for separation was $1.0 \mathrm{~mL}$.

Method optimized final chromatographic conditions: After method development, the method was evaluated for the optimization of ion chromatographic conditions and validation has been done as per the ICHQ2 (R1). The chromatographic conditions were the column of $\mathrm{C}_{4} 250 \times 4.0 \times 250 \mathrm{~mm} \times 5.0 \mu \mathrm{m}$, Mobil phase as $3 \mathrm{mM}$ nitric acid and $0.1 \mathrm{mM}$ dipicolinic acid mixed buffer $90 \%$ and acetonitrile $10 \%$. The flow of mobile phase used for separation was $1.0 \mathrm{~mL} / \mathrm{min}$; the loop volume was $20 \mu \mathrm{L}$ for the standard, sample load and conductivity detector. The diluent used was 50:50 acetonitrile and water with ratio of 50:50 (\% v/v). The sample concentrations were fixed for the sodium in pantoprazole sodium, potassium in losartan potassium and magnesium in omeprazole magnesium as $0.2,0.1$ and 0.3 $\mathrm{mg} / \mathrm{mL}$, respectively. Finally, the single ion chromatographic method was used to determining the different percentages of counter ions in three drug substances.

Specificity: The specificity of the present method by ion chromatography is shown in Fig. 3. There was no interference among sodium, potassium and magnesium as well as lithium, ammonium and calcium. The specificity was performed by injecting system stability, blank and individual counter ions and mixed counter ions in presence of pantoprazole sodium, losartan potassium and omeprazole magnesium. Specificity results are given in Table-1.

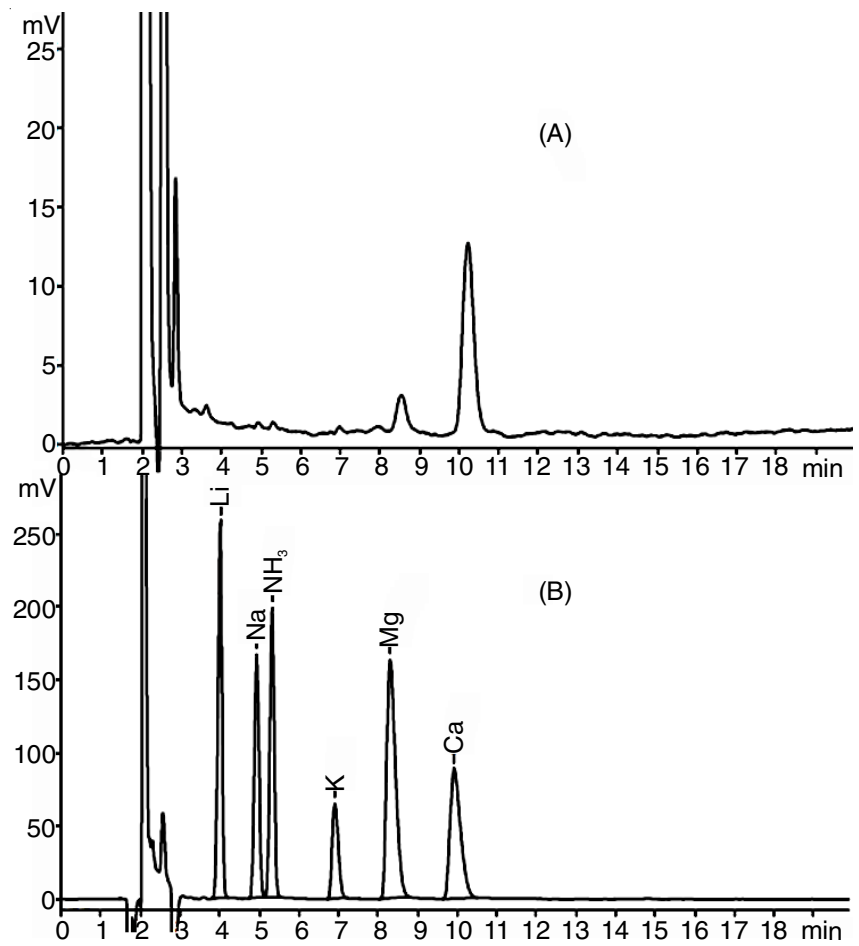

Fig. 3. Specificity chromatograms (A) Blank (B) Blend chromatogram 


\begin{tabular}{clc}
\hline \multicolumn{3}{c}{ TABLE-1 } \\
& \multicolumn{1}{c}{ SPECIFICITY RESULTS } \\
\hline S. No & \multicolumn{1}{c}{ Counter ions } & Retention time (min) \\
\hline 1 & Lithium & 4.0 \\
2 & Sodium & 4.9 \\
3 & Ammonium & 5.3 \\
4 & Potassium & 6.9 \\
5 & Magnesium & 8.3 \\
6 & Calcium & 9.9 \\
\hline
\end{tabular}

Precision: Precision of the method was demonstrated by method precision and intermediate precision at 5.7 of sodium in pantoprazole sodium, $8.5 \%$ of potassium in losartan potassium and $3.3 \%$ magnesium in omeprazole magnesium. The cumulative precision at intra and inter days were performed. The $\%$ RSD values were less than $5 \%$ for all counters, it describes the developed method was good. Precision results are given in Table-2.

Accuracy: The accuracy of method has been determined by doing the recovery studies at three different levels of counter ions at specification level. Six preparations were determined for the $100 \%$ level i.e. counter ion specification level and 150 $\%$ level and three preparations were performed at $50 \%$ level with respect to counter ion specification level. The $\%$ recovery was calculated with respect to the method precision. The $\%$ RSD for the counter ion at specification level, $50 \%$ and 150 were less than $10 \%$. The $\%$ recovery at 50, 100 and $150 \%$ were within the range in pantoprazole sodium, losartan potassium and omeprazole magnesium. The accuracy results are give in Table- 3 .

\begin{tabular}{cccc}
\multicolumn{4}{c}{ TABLE-3 } \\
& ACCURACY RESULTS \\
\hline Concentration & Sodium & Potassium & Magnesium \\
\hline Accuracy at 50\%-1 & 100 & 94 & 112 \\
Accuracy at 50 \%-2 & 93 & 101 & 115 \\
Accuracy at 50 \%-3 & 98 & 97 & 112 \\
Accuracy at 100 \%-1 & 99 & 93 & 97 \\
Accuracy at 100 \%-2 & 100 & 102 & 101 \\
Accuracy at $100 \%-3$ & 100 & 100 & 98 \\
Accuracy at $100 \%-4$ & 103 & 103 & 101 \\
Accuracy at $100 \%-5$ & 101 & 97 & 97 \\
Accuracy at $100 \%-6$ & 102 & 99 & 99 \\
Accuracy at $150 \%-1$ & 93 & 101 & 96 \\
Accuracy at $150 \%-2$ & 104 & 101 & 99 \\
Accuracy at $150 \%-3$ & 104 & 101 & 98 \\
Accuracy at $150 \%-4$ & 105 & 102 & 98 \\
Accuracy at $150 \%-5$ & 105 & 103 & 100 \\
Accuracy at $150 \%-6$ & 105 & 102 & 100 \\
\hline
\end{tabular}

Linearity and range: The seven standards were used to prove the linearity each counter ion in respective drug substance. The ranges of $12576 \mathrm{ppm}$ to $100608 \mathrm{ppm}$ were selected for sodium (1.4\% to 11.4 with respect to $5.7 \%)$ and the correlation coefficient was 1.000 . The range of 25242 to 201936 ppm was selected for potassium (2.1\% to 17 with respect to $8.5 \%$ ) and the correlation coefficient was 0.999 . The range of $7898 \mathrm{ppm}$ to $63180 \mathrm{ppm}$ was selected for sodium $(0.8 \%$ to 6.6 with respect to $3.3 \%$ ) and the correlation coefficient was 1.000. The calibrations of sodium, potassium and magnesium are shown in Fig. 4.
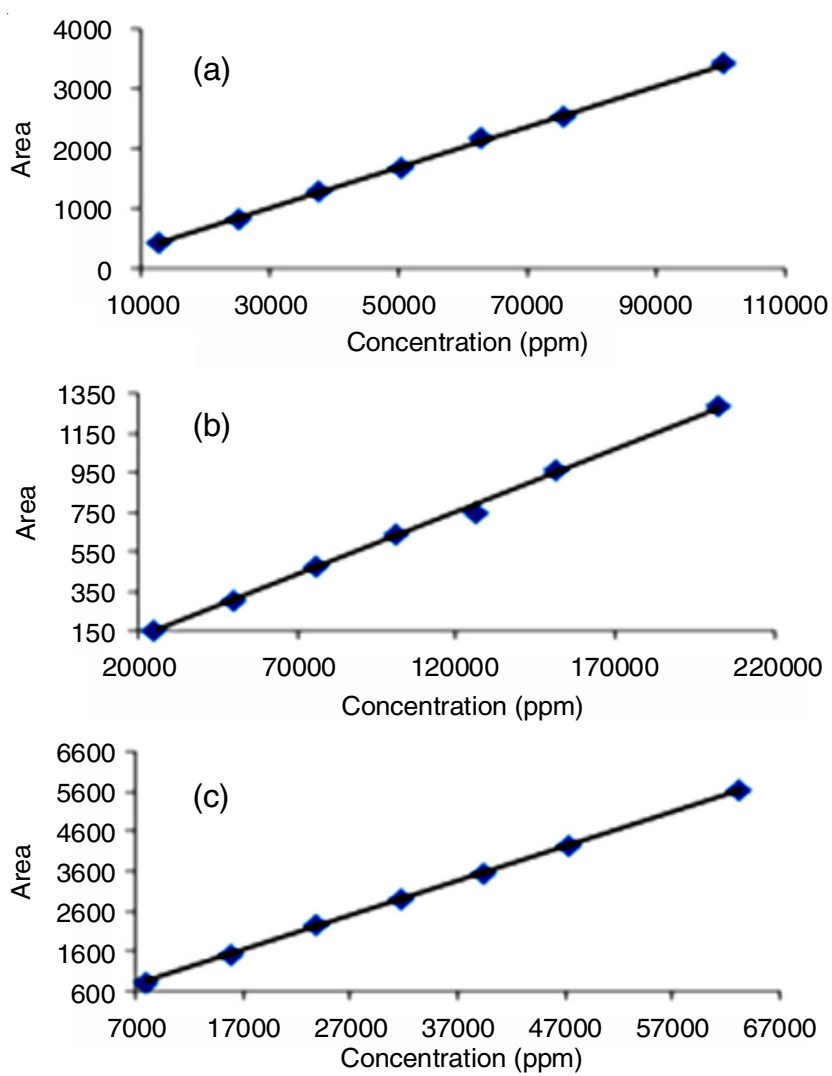

Fig. 4. Calibration curves of (a) sodium, (b) potassium and (c) magnesium

Robustness: The robustness was studied by slight variation of actual method parameters such as flow, acid strength, the present change of organic solvent. Five injections of mixed standard were injected and \% RSD of three counter ions was calculated that was less than $10 \%$ in all robustness conditions. The robustness results are given in Table- 4 .

Solution stability and mobile phase stability: The solution and mobile phase stability was evaluated by injecting the stored solution with intervals of $0,12,24,48$ and $72 \mathrm{~h}$. The variation of the counter ion contents were reported which were less than $10 \%$ with respect to initial analysis. Similarly freshly samples counter ions content were evaluated with stored mobile phase under same chromatographic conditions with intervals of $0,12,24,48$ and $72 \mathrm{~h}$, the variation of the counter ion

\begin{tabular}{|c|c|c|c|c|c|c|}
\hline \multicolumn{7}{|c|}{$\begin{array}{c}\text { TABLE-2 } \\
\text { PRECISION RESULTS }\end{array}$} \\
\hline \multirow[b]{2}{*}{ Counter ion } & \multirow[b]{2}{*}{ Drug substance } & \multirow[b]{2}{*}{$\begin{array}{l}\text { Theoretical \% } \\
\text { of counter ion }\end{array}$} & \multicolumn{4}{|c|}{$\operatorname{RSD}(\%)$} \\
\hline & & & $\begin{array}{c}\text { Method } \\
\text { precision }\end{array}$ & $\begin{array}{l}\text { Intermediate } \\
\text { precision }\end{array}$ & $\begin{array}{c}150 \% \text { level } \\
\text { precision }\end{array}$ & $\begin{array}{l}50 \% \text { level } \\
\text { precision }\end{array}$ \\
\hline Sodium & Pantoprazole sodium & 5.7 & 1.6 & 1.6 & 4.8 & 3.7 \\
\hline Potassium & Losartan potassium & 8.5 & 2.0 & 1.5 & 0.7 & 3.8 \\
\hline Magnesium & Omeprazole magnesium & 3.3 & 1.7 & 2.0 & 1.7 & 1.8 \\
\hline
\end{tabular}




\begin{tabular}{|c|c|c|c|c|c|c|c|c|}
\hline \multicolumn{9}{|c|}{$\begin{array}{c}\text { TABLE-4 } \\
\text { ROBUSTNESS RESULTS }\end{array}$} \\
\hline \multirow{2}{*}{ Parameter } & \multirow{2}{*}{ Actual value } & \multirow{2}{*}{$\begin{array}{l}\text { Changed } \\
\text { value }\end{array}$} & \multicolumn{2}{|c|}{ Sodium } & \multicolumn{2}{|c|}{ Potassium } & \multicolumn{2}{|c|}{ Magnesium } \\
\hline & & & Std.* & VCI. & Std.* & VCI. $^{\#}$ & Std.* & VCI. $^{\#}$ \\
\hline \multirow{2}{*}{ Flow rate } & \multirow{2}{*}{$1.0 \mathrm{~mL} / \mathrm{min}$} & $0.9 \mathrm{~mL} / \mathrm{min}$ & 0.7 & 2.7 & 0.8 & 8.8 & 1.5 & 0.8 \\
\hline & & $1.1 \mathrm{~mL} / \mathrm{min}$ & 1.0 & -2.6 & 0.7 & 1.4 & 0.7 & -4.4 \\
\hline \multirow{2}{*}{ Acetonitrile } & \multirow{2}{*}{$10 \%$} & $8 \%$ & 0.7 & 1.5 & 0.8 & -1.4 & 1.8 & -1.0 \\
\hline & & $12 \%$ & 0.7 & 0.3 & 0.7 & 3.3 & 0.6 & -2.3 \\
\hline \multirow{2}{*}{ Nitric acid } & \multirow{2}{*}{$4.0 \mathrm{Mm}$} & $3.6 \mathrm{Mm}$ & 1.0 & -0.5 & 0.9 & 2.5 & 1.1 & -2.7 \\
\hline & & $4.4 \mathrm{mM}$ & 1.1 & 0.8 & 0.8 & 4.7 & 1.1 & -0.8 \\
\hline
\end{tabular}

\begin{tabular}{|c|c|c|c|c|c|c|}
\hline \multicolumn{7}{|c|}{$\begin{array}{c}\text { TABLE-5 } \\
\text { SOLUTION STABILITY STUDY RESULTS }\end{array}$} \\
\hline Study (h) & $\begin{array}{l}\text { Sodium content } \\
(\%, \mathrm{w} / \mathrm{w})\end{array}$ & Variation (\%) & $\begin{array}{l}\text { Potassium content } \\
(\%, \mathrm{w} / \mathrm{w})\end{array}$ & Variation $(\%)$ & $\begin{array}{c}\text { Magnesium } \\
\text { content }(\%, w / w)\end{array}$ & Variation (\%) \\
\hline $0 \mathrm{~h}$ Solution stability & 5.5 & - & 8.1 & - & 3.0 & - \\
\hline $12 \mathrm{~h}$ Solution stability & 5.6 & 1.4 & 8.3 & 0.8 & 3.1 & 2.7 \\
\hline $24 \mathrm{~h}$ Solution stability & 5.7 & 3.7 & 8.4 & 3.5 & 3.2 & 5.5 \\
\hline $48 \mathrm{~h}$ Solution stability & 5.7 & 4.7 & 8.7 & 7.6 & 3.1 & 2.0 \\
\hline 72 h Solution stability & 5.9 & 8.0 & 9.1 & 10.4 & 3.3 & 8.9 \\
\hline $0 \mathrm{~h}$ Mobile phase stability & 5.6 & - & 8.2 & - & 3.1 & - \\
\hline $12 \mathrm{~h}$ Mobile phase stability & 5.6 & 1.4 & 8.3 & 1.4 & 3.2 & 3.0 \\
\hline $24 \mathrm{~h}$ Mobile phase stability & 5.7 & 1.9 & 8.2 & 0.5 & 3.1 & 1.6 \\
\hline $48 \mathrm{~h}$ Mobile phase stability & 5.7 & 2.7 & 8.5 & 5.0 & 3.1 & 0.0 \\
\hline $72 \mathrm{~h}$ Mobile phase stability & 5.8 & 4.2 & 8.8 & 7.0 & 3.3 & 5.6 \\
\hline
\end{tabular}

contents were reported which were less than $10 \%$ with respect to initial analysis. The solution and mobile phase stability data is given in Table-5.

\section{Conclusion}

A single counter ions convenient method was developed by ion chromatography for simultaneous determination of sodium, potassium and magnesium in pantoprazole sodium, losartan potassium and omeprazole magnesium, respectively. The best resolution was achieved by using Metrosep $\mathrm{C}_{4} 250 \times$ $4.0 \times 250 \mathrm{~mm} \times 5.0 \mu \mathrm{m}$ column, $4.0 \mathrm{mM}$ nitric acid and 0.1 $\mathrm{mM}$ dipicolinic acid mixer buffer and acetonitrile $10 \%$, with flow $1.0 \mathrm{~mL}$ and 20 micro $\mu \mathrm{L}$ load and conductivity detector. The method was validated for the precision, accuracy, linearity, range, robustness, solution and mobile phase stability. The method was specifying with remaining cat ions and it is precise, accurate, linear, robust, rugged and short runtime method for three counter ions in three drug substances, this can be used for routine analysis in quality control laboratories.

\section{ACKNOWLEDGEMENTS}

The author thanks to Dr. Reddy's Laboratories Ltd., Custom Pharmaceutical Services, Miyapur, Hyderabad, India to support to this work. The authors also acknowledge to Process Research and Development for their support and also thankful to Dr. H. Rama Mohan for his encouragement.

\section{CONFLICT OF INTEREST}

All the authors have no conflicts of interest regarding the publication of the article. Dr. Reddy's has provided communication number: IPDO IPM-00574 for this research.

\section{REFERENCES}

1. Q1A (R2) Stability Testing of New Drug Substances and Products.

2. S. Goswami and P.K. Das, J. Chromatogr. B Analyt. Technol. Biomed. Life Sci., 863, 9 (2008);

https://doi.org/10.1016/j.jchromb.2007.12.016.

3. Crystallineformofomeprazolesodiumsalt, https://patents.google.com/patent/DE69811892T2/en. https://patents.google.com/patent/WO2004037253A1/en.

4. A.P. Micheel, C.Y. Ko and H.Y. Guh, J. Chromatogr. B Biomed. Sci. Appl., 709, 166 (1998);

https://doi.org/10.1016/S0378-4347(98)00048-6.

5. L. Gonzalez, J.A. Lopez, R.M. Alonso and R.M. Jimenez, J. Chromatogr. A, 949, 49 (2002);

https://doi.org/10.1016/S0021-9673(01)01496-0.

6. N. Ferreiros, G. Iriarte, R. Alonso and R. Jimenez, Talanta, 73, 748 (2007); https://doi.org/10.1016/j.talanta.2007.04.062.

7. Indian Pharmacopoeia, Govt. of India, Ministry of Health and Family Welfare, Published by The Controller of Publications: New Delhi, vol. II (1996).

8. J. Pentchuk, P. Alumaa, J. Ivask and M. Käärik, Proc. Estonian Acad. Sci. Chem., 54, 189 (2005).

9. H. Small, Ion Chromatography, Plenum Press, New York (1989).

10. J. Weiss, Ion Chromatography, VCH, Weinheim, edn 2 (1995).

11. S. Schnell, S. Ratering and K. Jansen, Environ. Sci. Technol., 32, 1530 (1998); https://doi.org/10.1021/es $970861 \mathrm{~g}$

12. USEPA Method, 300.7, Dissolved Sodium, Ammonium, Potassium, Magnesium and Calcium in Wet Depositionby Chemically Suppressed Ion Chromatography, USEPA, Cincinnati, OH, USA (1986).

13. Australian Standard AS 3741-1990, Recommended Practice for Chemical Analysis by Ion Chromatography, Standards Australia, North Sydney, NSW (1990).

14. K.A. Welch, W.B. Lyons, E. Graham, K. Neumann, J.M. Thomas and D. Mikesell, J. Chromatogr. A, 739, 257 (1996); https://doi.org/10.1016/0021-9673(96)00044-1.

15. J. Ivask and J. Pentchuk, J. Chromatogr. A, 770, 125 (1997); https://doi.org/10.1016/S0021-9673(96)01084-9.

16. N. Gros and B. Gorenc, J. Chromatogr. A, 789, 323 (1997); https://doi.org/10.1016/S0021-9673(97)00781-4. 
17. N. Gros and B. Gorenc, J. Chromatogr. A, 770, 119 (1997); https://doi.org/10.1016/S0021-9673(97)00060-5.

18. D.A. Shah, A. Patel, S.L. Baldania, U.K. Chhalotiya and K.K. Bhatt, ISRN Spectrosc., Article ID 459820 (2013); https://doi.org/10.1155/2013/459820.

19. S.S. Perumal, S.P. Ekambaram and S. Raja, J. Food Drug Anal., 22, 520 (2014); https://doi.org/10.1016/j.jfda.2014.05.003.

20. K. Lakshmidurga, T.R.M. Reddy, A. Ajitha and V.U.M. Rao, J. Pharm. Chem., 8, 14 (2014).

21. T.J. Chaudhary and S. Bhadani, Am. J. PharmTech Res., 3, 2249 (2013).

22. G.A. Phadtare, S.C. Daswadkar and M.A. Kuchekar, Int. J. Appl. Pharm. Arch., 1, 92 (2016).

23. S. Pandey, P. Pandey, D. Mishra and U.K. Singh, Braz. J. Pharm. Sci., 49, 175 (2013); https://doi.org/10.1590/S1984-82502013000100019.

24. A. Kumar, M. Debnath, B. Vinod and J.V.L.N. Seshagiri Rao, Int. J. Pharmacol. Pharm. Sci., 3, 19 (2016).

25. F Ali, G.N. Singh, P.L. Sahu, A. Prakash, M. Trivedi and T.A. Khan, World J. Pharm. Pharm. Sci., 4, 1145 (2015).

26. S. Ashour and S. Omar, Arab. J. Chem., 9, S114 (2016); https://doi.org/10.1016/j.arabjc.2011.02.010.

27. D. Bageshwar, V. Khanvilkar and V. Kadam, J. Pharm. Anal., 1, 275 (2011); https://doi.org/10.1016/j.jpha.2011.09.012.

28. K.E. McCarthy, Q. Wang, E.W. Tsai, R.E. Gilbert, D.P. Ip and M.A. Brooks, J. Pharm. Biomed. Anal., 17, 671 (1998); https://doi.org/10.1016/S0731-7085(97)00251-3.

29. S.U. Rakesh, P.R. Patil, P.N. Dhabale and K.B. Burade, J. Pharmacy Res., 2, 1252 (2009).

30. M.S. Kishore and K.K. Kumar, Der Pharm. Chem., 6, 171 (2014).

31. M. Stolarczyk, A. Maslanka, A. Apola and J. Krzek, Acta Pol. Pharm., 70, 967 (2013)

32. H.M. Hafez, A.A. Elshanawane, L.M. Abdelaziz and M.M. Kamal, Iran. J. Pharm. Res., 12, 635 (2013).

33. M.S. Kishore, K.K. Kumar, G. Ramu and C. Rambabu, Der Pharm. Lett., 7, 75 (2015).

34. A. Farnoudian-Habibi, S. Kangari, B. Massoumi and M. Jaymand, RSC Adv., 5, 102895 (2015); https://doi.org/10.1039/C5RA20117A.

35. S.V.S.G.B. Prasad, S. Shivakumar, T. Sudhir, R. Mital and G.D. Rao, Int. J. Pharm. Pharm. Sci., 1 (Suppl. 1), 206 (2009).

36. B. Patel, M. Patel, J. Patel and B. Suhagiam, J. Liq. Chromatogr. Rel. Technol., 30, 1762 (2006); https://doi.org/10.1080/10826070701360368.

37. H. Salem, S.M Riad, M.R. Rezk and K. Ahmed, J. Chromatogr. Sep. Techniq., 5, 221 (2014); https://doi.org/10.4172/2157-7064.1000221.
38. S.M. Gosavi and M.A. Tayade, J. Chromatogr. Sep. Techniq., 8, 360 (2017); https://doi.org/10.4172/2157-7064.1000360.

39. L. Sivasubramanian and V. Anilkumar, Indian J. Pharm. Sci., 69, 674 (2007); https://doi.org/10.4103/0250-474X.38474.

40. W.-K. Kang, D.-S. Kim, K.-I. Kwon, Arch. Pharm. Res., 22, 86 (1999); https://doi.org/10.1007/BF02976443.

41. M. Altun, D. Karakas and G. Bilsel, J. Chem. Metrol., 10, 27 (2016);

42. L. Zanitti, R. Ferretti, B. Gallinella, F. La Torre, M.L. Sanna, A. Mosca and R. Cirilli, J. Pharm. Biomed. Anal., 52, 665 (2010); https://doi.org/10.1016/j.jpba.2010.02.021.

43. M. Ribani, C.H. Collins and C.B.G. Bottoli, J. Chromatogr. A, 1156, 201 (2007); https://doi.org/10.1016/j.chroma.2006.12.080.

44. W. Zhao, S. Leroux, V. Biran and E. Jacqz-Aigrain, Br. J. Clin. Pharmacol., 84, 997 (2018); https://doi.org/10.1111/bcp.13526.

45. S. Gopalakrishnan, K. Jothy and K. Dhanalakshmi, Elixir Appl. Chem., 52, 11283 (2012).

46. Vijayaraghavan, G. Jayababu, R. Prasad, P.E. Thirugnanam, V.T. Sriraam, G. Shivkumar, V.T. Sriraam and G. Ramesh Kumar, Int. J. Pharm. Sci. Res., 2, 2475 (2011); https://doi.org/10.13040/IJPSR.0975-8232.2(9).2475-81.

47. R.T. Addo, K. Davis, R. Ubale, J.S. Owen and E.B. Watkins, AAPS PharmSciTech., 16, 30 (2015); https://doi.org/10.1208/s12249-014-0207-7.

48. The United States Pharmacopoeia 39 and National Formulary 34, United States Pharmacopoeia, Rockville Convection (2016).

49. International Conference on Harmonization, Q2 (R1), Validation of Analytical Procedures: Text and Methodology, ICH Guidelines (2005).

50. International Conference on Harmonization, Q1B, Photo-stability Testing of New Drug Substances and Products, ICH Guidelines (1996).

51. P.M. Hald, J. Biol. Chem., 167, 499 (1947).

52. B. Sen, Fresenius' Z. Anal. Chem., 157, 2 (1957); https://doi.org/10.1007/BF00458072.

53. R.B. Muter and C.F. Cockrell, Appl. Spectrosc., 23, 493 (1969); https://doi.org/10.1366/000370269774380572.

54. V.A. Murphy, Anal. Biochem., 161, 144 (1987); https://doi.org/10.1016/0003-2697(87)90664-6.

55. C.V.S. Ieggli, D. Bohrer, P.C. do Nascimento, L.M. de Carvalho and S.C. Garcia, Talanta, 80, 1282 (2010); https://doi.org/10.1016/j.talanta.2009.09.024.

56. A. Krejcová, T. Cernohorský and E. Curdová, J. Anal. At. Spectrom., 16, 1002 (2001); https://doi.org/10.1039/B101941O. 